\title{
Efficient simultaneous production of extracellular polyol esters of fatty acids and intracellular lipids from inulin by a deep-sea yeast Rhodotorula paludigena P4R5
}

\author{
Mengqi Wang ${ }^{1 \dagger}$, Weian Mao ${ }^{1 \dagger}$, Xiaoxiang Wang ${ }^{1}$, Fengyi $\mathrm{Li}^{1}$, Jiming Wang ${ }^{3}$, Zhe Chi $^{1,2}$, Zhenming Chi ${ }^{1,2}$ \\ and Guanglei Liu ${ }^{1,2^{*}}$ (D)
}

\begin{abstract}
Background: Polyol esters of fatty acids (PEFA) are a kind of promising biosurfactants and mainly secreted by Rhodotorula strains. In addition, some strains of Rhodotorula are reliable producers of microbial lipid. Therefore, it is feasible to establish a one step fermentation process for efficient simultaneous production of PEFA and microbial lipids by a suitable Rhodotorula strain.

Results: A newly isolated deep-sea yeast, Rhodotorula paludigena P4R5, was shown to simultaneously produce high level of intracellular lipid and extracellular PEFA. Under the optimized conditions, it could yield $48.5 \mathrm{~g} / \mathrm{L}$ of PEFA and $16.9 \mathrm{~g} / \mathrm{L}$ of intracellular lipid within $156 \mathrm{~h}$ from inulin during 10-L batch fermentation. The PEFA consisting of a mixture of mannitol esters of 3-hydroxy $C_{14}, C_{16}$ and $C_{18}$ fatty acids with variable acetylation showed outstanding surface activity and emulsifying activity, while the fatty acids of the intracellular lipid were mainly $C_{16}$ and $C_{18}$ and could be high-quality feedstock for biodiesel production.

Conclusion: The deep-sea yeast strain R. paludigena P4R5 was an excellent candidate for efficient simultaneous of biosurfactants and biodiesel from inulin. Our results also suggested that the establishment of fermentation systems with multiple metabolites production was an effective approach to improve the profitability.
\end{abstract}

Keywords: Rhodotorula paludigena, Biosurfactant, Microbial lipid, Biodiesel, Inulin

\section{Background}

Marine yeasts live in harsh environments, and this provides the potential for several unique desirable properties to be used in various industries, including higher osmosis tolerance, higher special chemical productivity and production of industrial enzymes [1]. Therefore, marine yeasts have great potential application in food, pharmaceutical, cosmetic and chemical industries as well as marine culture and environmental protection.

\footnotetext{
*Correspondence: liug|@ouc.edu.cn

${ }^{\dagger}$ Mengqi Wang and Weian Mao contributed equally to this work

${ }^{1}$ College of Marine Life Science, Ocean University of China, Yushan Road,

No. 5, Qingdao 266003, Shandong, China

Full list of author information is available at the end of the article
}

The predominant yeasts derived in marine environments are red yeasts, which are primarily members of the genera Rhodotorula, Rhodosporidium and Sporobolomyces [2]. Among these, yeast species of the anamorphic genus Rhodotorula have been recognized as a reliable producer of carotenoids, enzymes, microbial oils and biosurfactants [3-5]. Thus, the strains of Rhodotorula, especially from marine environments, are of great biotechnological potential and deserve further study and exploration.

Biosurfactants are a structurally diverse group of amphipathic substances molecules synthesized by bacteria, yeasts or fungi [6]. In comparison to chemical surfactants, biosurfactants possess lower toxicity, higher biodegradability and environmental compatibility, and

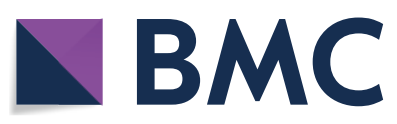

(c) The Author(s) 2019. This article is distributed under the terms of the Creative Commons Attribution 4.0 International License (http://creativecommons.org/licenses/by/4.0/), which permits unrestricted use, distribution, and reproduction in any medium, provided you give appropriate credit to the original author(s) and the source, provide a link to the Creative Commons license, and indicate if changes were made. The Creative Commons Public Domain Dedication waiver (http://creativecommons.org/ publicdomain/zero/1.0/) applies to the data made available in this article, unless otherwise stated. 
can be produced from regenerated biomass resources and industrial by-products [7]. Therefore, in addition to classical cleaning applications, they have promising applications in environmental protection, crude-oil recovery, food-processing, biofilm prevention and disruption, and in various fields of biomedicine [8-10]. Glycolipids are a group of the most common biosurfactants and mainly consist of sophorolipids, mannosylerythritol lipid, cellobiose lipids, liamocins and polyol esters of fatty acids [4]. Among these, polyol esters of fatty acids (PEFA) are composed of an acetylated $(R)$ 3-hydroxy fatty acid esterified through the carboxyl end to a 5 or 6 carbon polyol, typically D-mannitol or $\mathrm{D}$-arabitol, with varying degrees of acetylation [11]. Intriguingly, the PEFA secreting strains are mostly belong to the genus Rhodotorula [12]. Specifically, Rhodotorula babjevae [13], Rhodotorula taiwanensis [14], Rhodotorula aff. paludigena [15] have been reported to be potential PEFA producers for commercial application. In addition to PEFA, yeast species of the genus Rhodotorula have prodigious potential and extensive foreground in intracellular lipids production, known as single cell oils, which serve as precursors for biofuels, oleochemicals and food products. For instance, an oleaginous yeast strain Rhodotorula toruloides Y4 could produce high cellular lipid content of over $70 \%$ and high cell density of $100 \mathrm{~g} / \mathrm{L}$ [16].

So far, high production costs are still a main barrier to the commercialization of microbial oils and glycolipids [7]. To overcome this constraint, the establishment of fermentation systems with multiple metabolites production is a promising solution, due to the efficient utilization of fermentation equipment and feedstock [17]. Moreover, both the biosynthesis of glycolipids and intracellular lipids involve fatty acid synthesis pathway, which is enhanced under the conditions of carbon excess and nitrogen limiting (high $\mathrm{C}: \mathrm{N}$ ratio) [3, 15]. In our previous study, Aureobasidium melanogenum 9-1 could simultaneously produce $27.4 \pm 0.3 \mathrm{~g} / \mathrm{L}$ liamocins and $22.6 \pm 0.8 \%$ $(\mathrm{w} / \mathrm{w})$ intracellular lipids within $168 \mathrm{~h}$ [18]. Many efforts have concentrated on using industrial waste and raw biomass materials as low-cost carbon sources, such as molasses, whey, industrial fats, glycerol, cassava and lignocellulose [19]. In addition, inulin, a linear polysaccharide $(\beta$-2,1-linked $\mathrm{D}$-fructose residues terminated by a glucose residue) presented as a storage carbohydrate in plants such as chicory, Jerusalem artichoke and dahlia, has also received attention as a renewable non-food biomass resource for the production of ethanol, pullulan, single cell oil, citric acid and other chemicals [20-22]. However, the utilization efficiency of inulin depends on the native or heterogenous inulinase activity of yeast strains.
In the present study, a deep-sea yeast strain Rhodotorula paludigena P4R5 was isolated and identified. This strain possessed high-level inulinase activity, and could simultaneously produce high quantities of extracellular PEFA and intracellular lipids from inulin. The produced PEFA and intracellular lipids were analyzed and characterized, indicating the potential of the strain P4R5 for the industrial production of biosurfactant and biodiesel.

\section{Results and discussion}

\section{Isolation and identification of high biosurfactant and lipid} producing yeasts from deep sea sediments

Forty-two strains of yeasts were isolated from sediment samples collected at a depth of $4067 \mathrm{~m}$ in the South Pacific $\left(18^{\circ} 29^{\prime} \mathrm{S}, 129^{\circ} 31^{\prime} \mathrm{W}\right)$. On the basis of morphological and physiological characteristics [23] and molecular identification, nineteen strains obtained were found to belong to the genus of Rhodotorula (Additional file 1: Table S1). Similarly, in a previous study, the proportions of red yeasts among the total yeasts isolated from deepsea sediments $(\geq 2000 \mathrm{~m})$ in the northwest Pacific Ocean was about $50 \%$, suggesting that red yeasts were the predominant yeasts detected in deep-sea environments [2]. Subsequently, to investigate the abilities of intracellular lipids and PEFA production, these nineteen strains were cultivated on the PEFA screening medium, and the yields of biomass, intracellular lipids and PEFA were analyzed within $144 \mathrm{~h}$ as described in "Materials and methods" and summarized in Additional file 1: Table S1. Specifically, the strain P4R5 could produce distinguishingly numerous hydrophobic droplets, displaying a yellowish and viscous appearance (Fig. 1A), and the morphologic investigation of the P4R5 culture under fluorescence microscopy via Nile red staining also revealed the presence of not only yellow fluorescent intracellular lipids but also red fluorescent lipid molecules in extracellular compartment, indicating the ability of simultaneous production of extracellular PEFA and intracellular lipids (Fig. 1B, C). Furthermore, intracellular lipid content and extracellular PEFA titer produced by strain P4R5 within $144 \mathrm{~h}$ were $48.9 \%(\mathrm{w} / \mathrm{w})$ and $12.7 \mathrm{~g} / \mathrm{L}$, respectively. Based on these particularity, the strain P4R5 was selected for further study. The sequence of the D1/D2 region of the $26 \mathrm{~S}$ rRNA gene of the strain P4R5 (Accession number: MH754705) showed 99\% with $99 \%$ that of Rhodotorula paludigena $\mathrm{CBS} 6566^{\mathrm{T}}$ (type strain). Furthermore, the topology of the phylogenetic tree in Fig. 2 confirmed that the yeast strain P4R5 belonged to the species $R$. paludigena. So far, the vast majority of the PEFA secreting yeast strains, mostly belonging to genus Rhodotorula, were isolated from plant surfaces [12]. Therefore, $R$. paludigena P4R5 isolated from deep sea was a new producer of extracellular PEFA and intracellular lipids. 

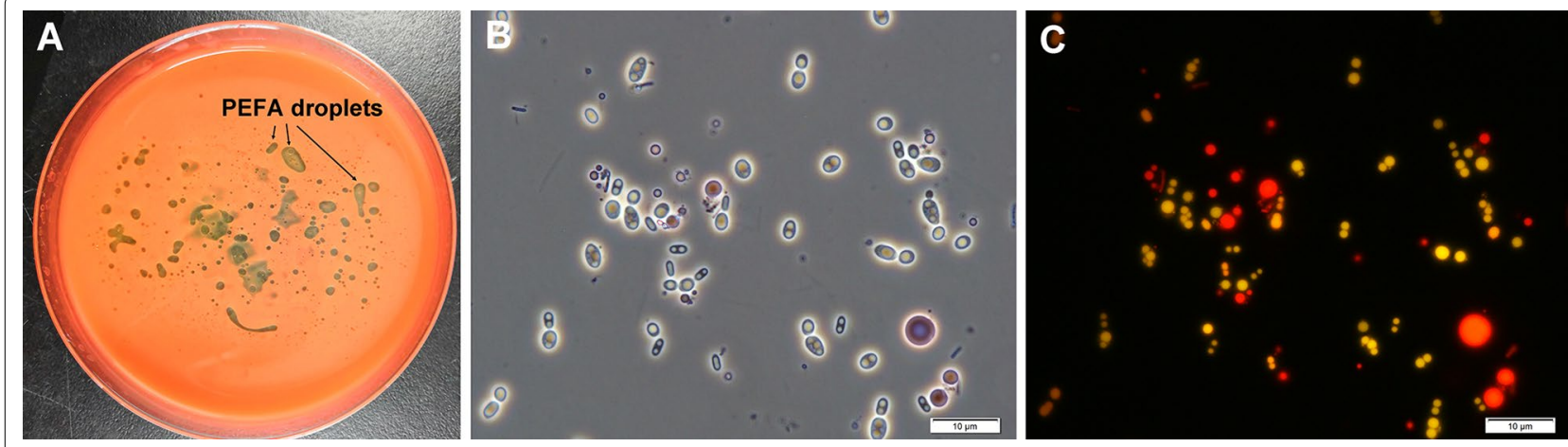

Fig. 1 The yellowish and hydrophobic PEFA droplets secreted by the strain P4R5 in the culture (A). Intracellular lipid particles (yellow ones) and extracellular liamocin particles (red ones) produced by the strain P4R5 was observed under a phase-contrast microscope (B) and a fluorescence microscope (C). The strain R4P5 was aerobically grown in the PEFA screening medium at $28^{\circ} \mathrm{C}$ for $144 \mathrm{~h}$, and the harvested culture broth was stained with Nile Red

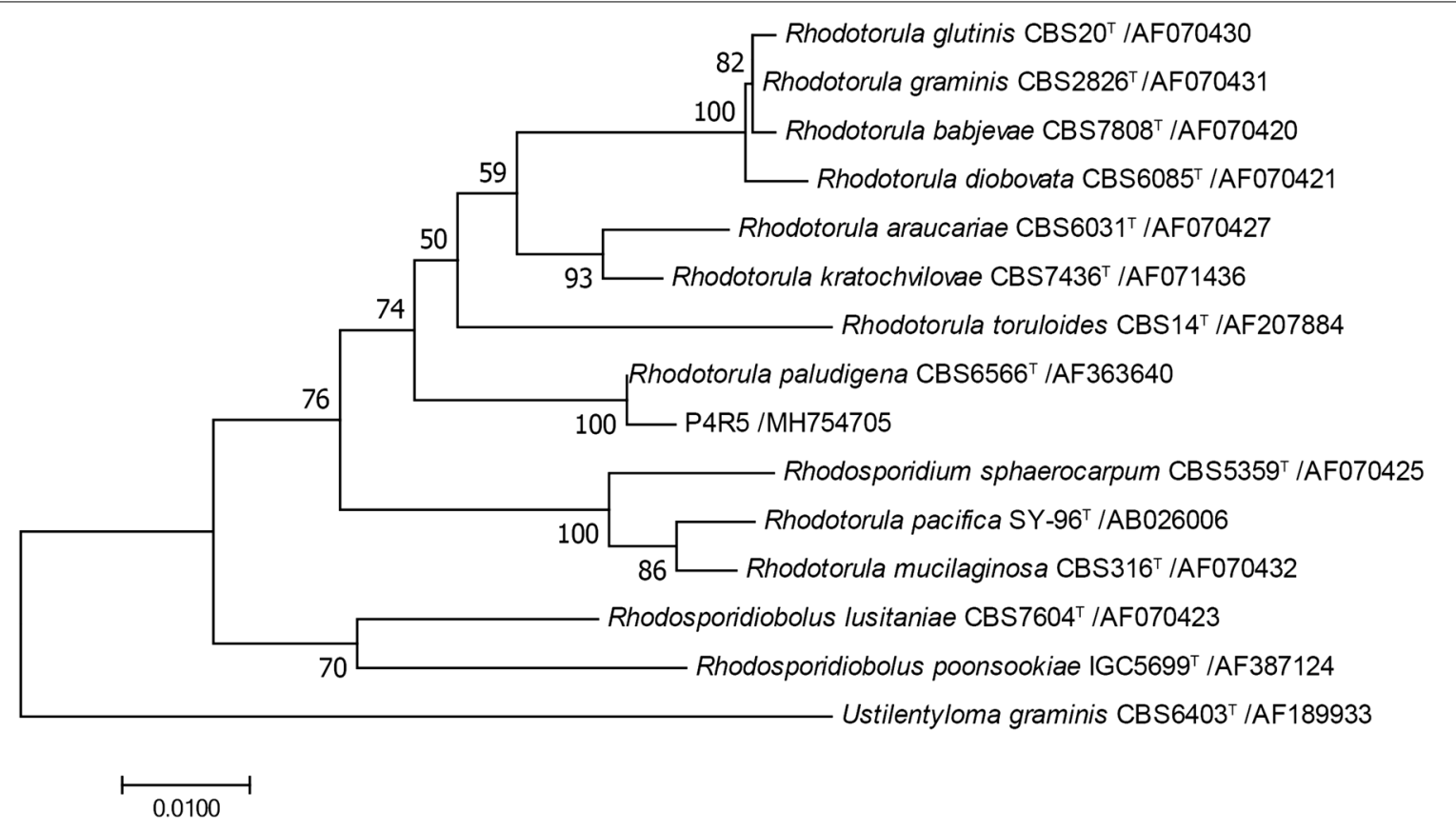

Fig. 2 The phylogenetic trees of the yeast strain P4R5 and other yeast relatives based on a neighbor-joining analysis of D1/D2 26S rDNA sequences. Bootstrap values at the notes are from 1000 replicates. ${ }^{\top}=$ type strain

\section{Analysis and characterization of PEFA and intracellular lipids produced by R. paludigena P4R5}

Each PEFA-secreting yeast produced a mixture of structurally similar PEFA, differing in the type of polyols attached, the degree of acetylation in the sugar alcohol, and the chain length of the 3-hydroxy fatty acid [4]. In order to characterize the fatty acid composition of PEFA and intracellular lipids in this study, the intracellular lipids and the extracellular PEFA produced from the strain P4R5 on the PEFA screening medium within $144 \mathrm{~h}$ were extracted and subjected to transmethylation for GC/MS analysis. As shown in Table 1, it was found that over $88 \%$ of the intracellular fatty acids from the strain P4R5 were $C_{16: 0}, C_{18: 0}, C_{18: 1}$ and $C_{18: 2}$, especially $C_{18: 1}$ (35.93\%). This composition was similar to those of the other oleaginous yeast lipids reported [22, 24, 25], and such yeast oils could be used as high-quality feedstock in biodiesel production that requires $\mathrm{C}_{16}-\mathrm{C}_{18}$ fatty acids [26]. For extracellular PEFA, the GC/MS analysis indicated the presence of three major hydroxyl fatty acids of 
Table 1 Fatty acid composition of the intracellular lipids and extracellular PEFA produced by $R$. paludigena P4R5 cultivated on PEFA screening medium for $144 \mathrm{~h}$

\begin{tabular}{lll}
\hline Composition & \multicolumn{2}{l}{ Percentage (\%) } \\
\cline { 2 - 3 } & $\begin{array}{l}\text { Intracellular } \\
\text { fatty acid }\end{array}$ & $\begin{array}{l}\text { Extracellular } \\
\text { fatty acid }\end{array}$ \\
\hline Tetradecanoic acid $\left(\mathrm{C}_{14: 0}\right)$ & 1.75 & - \\
3-Hydroxytetradecanoic acid (3-OH- $\left.\mathrm{C}_{14: 0}\right)$ & - & 4.40 \\
Hexadecanoic acid $\left(\mathrm{C}_{16: 0}\right)$ & 31.92 & - \\
2-Hexadecenoic acid $\left(\mathrm{C}_{16: 1}\right)$ & 0.55 & 7.50 \\
3-Hydroxyhexadecanoic acid (3-OH- $\left.\mathrm{C}_{16: 0}\right)$ & 6.51 & 70.51 \\
Octadecanoic acid $\left(\mathrm{C}_{18: 0}\right)$ & 6.13 & - \\
9-Octadecenoic acid $\left(\mathrm{C}_{18: 1}\right)$ & 35.93 & - \\
9,12-Octadecadienoic acid $\left(\mathrm{C}_{18: 2}\right)$ & 12.26 & - \\
9,12,15-Octadecatrienoic acid $\left(\mathrm{C}_{18: 3}\right)$ & 2.57 & - \\
2-Octadecenoic acid $\left(\mathrm{C}_{18: 1}\right)$ & - & 1.62 \\
3-Hydroxyoctadecanoic acid $\left(3-\mathrm{OH}-\mathrm{C}_{18: 0}\right)$ & 1.29 & 15.97 \\
Eicosanoic acid $\left(\mathrm{C}_{20: 0}\right)$ & 0.20 & \\
Docosanoic acid $\left(\mathrm{C}_{22: 0}\right)$ & 0.43 & \\
Tetracosanoic acid $\left(\mathrm{C}_{24: 0}\right)$ & 0.45 & \\
\hline
\end{tabular}

$3-\mathrm{OH}-\mathrm{C}_{14: 0}(4.40 \%), 3-\mathrm{OH}-\mathrm{C}_{16: 0}(70.51 \%)$ and 3-OH- $\mathrm{C}_{18: 0}$ $(15.97 \%)$, in addition to a small amount of 2-hexadecenoic acid and 2-octadecenoic acid, which were probably resulted from the dehydration of the corresponding 3-hydroxyl fatty acids during the methyl esterification process (Table 1). Notably, 3-hydroxyhexadecanoic acid $\left(3-\mathrm{OH}-\mathrm{C}_{16: 0}\right)$ and 3-hydroxyoctadecanoic acid (3-OH$\mathrm{C}_{18: 0}$ ) were also detected in the intracellular components. This suggested that the hydroxylation of fatty acids in the strain P4R5 reacted inside the cell, and this process was probably catalyzed an cytochrome $\mathrm{P} 450$ monooxygenase bound to the endoplasmic reticulum membrane according to the reported sophorolipid synthesis pathway and the genetic studies in the Rhodotorula strains [12, 27]. Based on the results above, the chain lengths of the 3-hydroxy fatty acids of the PEFA from the strain P4R5 were $\mathrm{C} 14, \mathrm{C} 16$ and $\mathrm{C} 18$.

To analyze the type of polyols and degree of acetylation, the polyols and acetic acid from the alkaline hydrolysate of the extracellular PEFA were determined by HPLC. According to the retention time of the standard substances, acetic acid and mannitol were detected with a molar ratio of 4.2 (Fig. 3). This result indicated that the polyol group of the PEFA from strain P4R5 was only mannitol, and the average degree of acetylation in the mannitol was 3.2, considering the acetylation in the 3-hydroxy of fatty acid in all yeast-secreting PEFA congeners reported $[4,15,17]$. It has demonstrated that

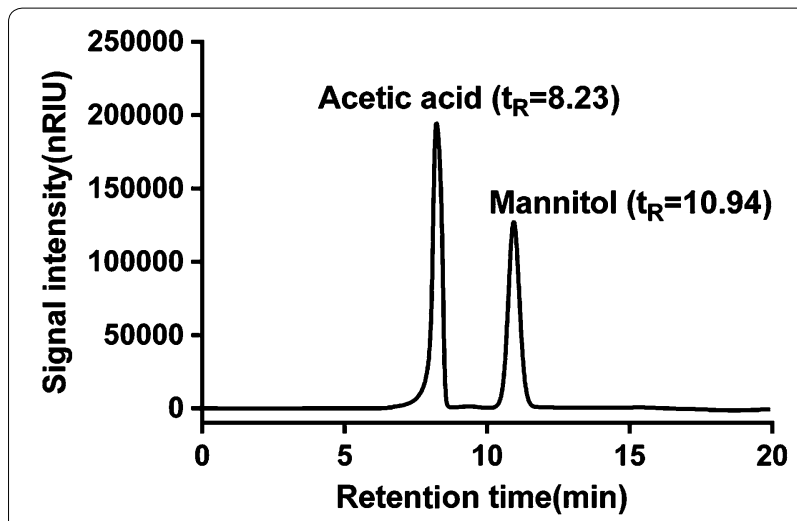

Fig. 3 HPLC analysis of polyols and acetic acid. According to the retention time of the standard substances, acetic acid and mannitol were detected

the acetylation of polyol groups on impacted the hydrophilic-lipophilic balance of PEFA, and hyper-acetylated PEFA having a low surfactant activity [14]. Therefore, the PEFA produced by $R$. paludigena P4R5 with the moderate acetylation could be effective and worthy of exploitation as a new biosurfactant.

The PEFA produced by $R$. paludigena P4R5 were further analyzed by liquid chromatography-electrospray ionization-mass spectrometry (LC-ESI-MS). The mass spectral ions were identified by calculation of elemental composition and comparison with available literature $[4,15,17]$. The result in Table 2 revealed the presence of at least 13 major fractions with molecular mass range of $\mathrm{m} / z$ 501.26-711.30, including acetylated 3-hydroxy hydroxytetradecanoic acid esterified to D-mannitol with 1-4 acetylation, acetylated 3-hydroxy hydroxyhexadecanoic acid esterified to mannitol with $0-5$ acetylation, and acetylated 3-hydroxy hydroxyoctadecanoic acid esterified to mannitol with 0 and $2-4$ acetylation. These results corroborated the findings of the fatty acid composition (Table 1) and the polyols type analysis (Fig. 3).

In conclusion, the PEFA produced by $R$. paludigena P4R5 were found to be a mixture of mannitol esters of 3-hydroxy fatty acids with variable acetylation. This result was basically in correlation with the composition identified in other strains of Rhodotorula yeast such as $R$. babjevae Y-SL7, $R$. aff. paludigena UCDFST, $R$. babjevae UCDFST 04-877 and $R$. taiwanensis MD1149 [14, 15, 17]. However, in addition to different degrees of acetylation, the major difference was the absence the arabitol esters of 3-hydroxy fatty acids in the PEFA of $R$. paludigena P4R5. This could be attributable to the genetic diversification of different strains. 
Table 2 Identification of PEFA produced by R. paludigena P4R5 cultivated on PEFA screening medium for $144 \mathrm{~h}$

\begin{tabular}{|c|c|c|c|}
\hline PEFA no. & Chemical formula & $\mathrm{m} / \mathrm{z}[\mathrm{M}+\mathrm{Na}]^{+}$ & Description \\
\hline 1 & $\mathrm{C}_{24} \mathrm{H}_{44} \mathrm{O}_{10}$ & 515.28 & Acetylated C14:0 3-hydroxy fatty acid esterified to mannitol with 1 acetylation \\
\hline 2 & $\mathrm{C}_{26} \mathrm{H}_{46} \mathrm{O}_{11}$ & 557.28 & Acetylated C14:0 3-hydroxy fatty acid esterified to mannitol with 2 acetylations \\
\hline 3 & $\mathrm{C}_{28} \mathrm{H}_{48} \mathrm{O}_{12}$ & 599.31 & Acetylated C14:0 3-hydroxy fatty acid esterified to mannitol with 3 acetylations \\
\hline 4 & $\mathrm{C}_{30} \mathrm{H}_{50} \mathrm{O}_{13}$ & 641.34 & Acetylated C14:0 3-hydroxy fatty acid esterified to mannitol with 4 acetylations \\
\hline 5 & $\mathrm{C}_{24} \mathrm{H}_{46} \mathrm{O}_{9}$ & 501.26 & Acetylated C16:0 3-hydroxy fatty acid esterified to mannitol with 0 acetylation \\
\hline 6 & $\mathrm{C}_{26} \mathrm{H}_{48} \mathrm{O}_{10}$ & 543.33 & Acetylated C16:0 3-hydroxy fatty acid esterified to mannitol with 1 acetylation \\
\hline 7 & $\mathrm{C}_{28} \mathrm{H}_{50} \mathrm{O}_{11}$ & 585.32 & Acetylated C16:0 3-hydroxy fatty acid esterified to mannitol with 2 acetylations \\
\hline 8 & $\mathrm{C}_{32} \mathrm{H}_{54} \mathrm{O}_{13}$ & 669.38 & Acetylated C16:0 3-hydroxy fatty acid esterified to mannitol with 4 acetylations \\
\hline 9 & $\mathrm{C}_{34} \mathrm{H}_{56} \mathrm{O}_{14}$ & 711.30 & Acetylated C16:0 3-hydroxy fatty acid esterified to mannitol with 5 acetylations \\
\hline 10 & $\mathrm{C}_{26} \mathrm{H}_{50} \mathrm{O}_{9}$ & 529.34 & Acetylated C18:0 3-hydroxy fatty acid esterified to mannitol with 0 acetylation \\
\hline 11 & $\mathrm{C}_{30} \mathrm{H}_{54} \mathrm{O}_{11}$ & 613.40 & Acetylated C18:0 3-hydroxy fatty acid esterified to mannitol with 2 acetylations \\
\hline 12 & $\mathrm{C}_{32} \mathrm{H}_{56} \mathrm{O}_{12}$ & 655.32 & Acetylated C18:0 3-hydroxy fatty acid esterified to mannitol with 3 acetylations \\
\hline 13 & $\mathrm{C}_{34} \mathrm{H}_{58} \mathrm{O}_{13}$ & 697.39 & Acetylated C18:0 3-hydroxy fatty acid esterified to mannitol with 4 acetylations \\
\hline
\end{tabular}

\section{Effect of different concentrations of glucose on PEFA and intracellular lipids production}

Unlike some glycolipids consisted of short chain fatty acids, such as liamocins from Aureobasidium melanogenum (hydroxy decanoic acid) [18], the fatty acid precursors of PEFA in $R$. paludigena P4R 5 were mainly $\mathrm{C}_{16}$ and $\mathrm{C}_{18}$ (Tables 1,2 ). This meant that the synthesis of PEFA and intracellular lipids shared the same fatty acid synthesis pathway, followed by linking with a glycerol or glycosidic molecule to generate triacylgycerols (TAG) or glycolipids, respectively [27]. Therefore, to simultaneously improve the production of PEFA and intracellular lipids, prior efforts should focused on enhancing fatty acid synthesis pathway. For oleaginous yeasts, it has been well documented that a high initial $\mathrm{C} / \mathrm{N}$ ratio (nitrogen starvation) in the medium is required to boost fatty acid synthesis [3]. Therefore, to improve the PEFA and lipid production by the strain P4R5, it was very important to optimize the glucose concentration in the PEFA screening medium. As shown in Fig. 4A, when the medium contained $120.0 \mathrm{~g} / \mathrm{L}$ glucose, both the intercellular lipid content and the extracellular PEFA titer reached the highest amount $(51.4 \%$ and $14.1 \mathrm{~g} / \mathrm{L}$, respectively) and cell dry weight was $31.0 \mathrm{~g} / \mathrm{L}$ within $144 \mathrm{~h}$. Notably, this extracellular PEFA titer $(14.1 \mathrm{~g} / \mathrm{L})$ were higher than those of other reported Rhodotorula strains from glucose at flask level [12], such as $R$. aff. paludigena UCDFST 81-84 (12.4 g/L), $R$. paludigena UCDFST $81-492$ (11.7 g/L) $R$. babjevae UCDFST 04-830 (8.5 g/L). This suggested that the strain P4R5 in this study had an superior capacity of PEFA production. With regard to $\mathrm{C} / \mathrm{N}$ molar ratio, the initial value was 89.5 in the optimum medium for PEFA production, considering the presence of $1.0 \mathrm{~g} / \mathrm{L}$ yeast and $0.2 \mathrm{~g} / \mathrm{L}$ ammonium sulfate and $120.0 \mathrm{~g} / \mathrm{L}$ glucose. In a previous study, the strain $R$. babjevae Y-SL7 reached the highest production of intra and extracellular lipids (3.5 and $4.4 \mathrm{~g} / \mathrm{L}$, respectively) at a $\mathrm{C} / \mathrm{N}$ molar ratio of 100 [17]. These results verified that the sharp initial $\mathrm{C} / \mathrm{N}$ ratio enhanced fatty acid synthesis and further pushed the formation of TAG and PEFA. However, as shown in Fig. 4A, when the glucose concentration increased to $140.0 \mathrm{~g} / \mathrm{L}$, the production of both the intercellular lipids and the PEFA began to drop. The trend was likely ascribed to the effect of osmotic stress caused by high concentration of glucose.

\section{The advantages of inulin over glucose for PEFA production} In addition to glucose, inulin also has received considerable attention as a renewable and competitive non-food biomass resource for microbial lipids production by oleaginous yeasts [20, 22]. For examples, the yeast strains R. toruloides 2F5 and Pichia guilliermondii Pcla22 could produce $70.36 \%$ and $60.6 \%(\mathrm{w} / \mathrm{w})$ of lipid based on cell dry weight from inulin due to their native exo-inulinase genes, respectively [24, 25]. However, the data available in literature scarcely involved the PEFA production from inulin. In this study, the strain P4R5 could produce inulinase activity of $34.6 \mathrm{U} / \mathrm{mL}$ within $72 \mathrm{~h}$ in the inulinase production medium, suggesting its potential of direct conversion of inulin into PEFA and cell lipid. To provide further evidence, the inulinase gene of the strain $R$. paludigena P4R5 was cloned and sequenced. The obtained inulinase gene (RpINU) had 2068 bp and four exons encoding a protein with 618 amino acids (Accession number: MH924353). Sequence alignment in Fig. 5 revealed that the amino acids deduced from the $R p I N U$ gene contained the conserved motifs of MNDPNGL, Q, FS, RDP and ECP, which were presented as characterized motifs in exo-inulinases [20]. According to the catalytic mechanism reported previously, the residues $\mathrm{Asp}^{141}$ and 

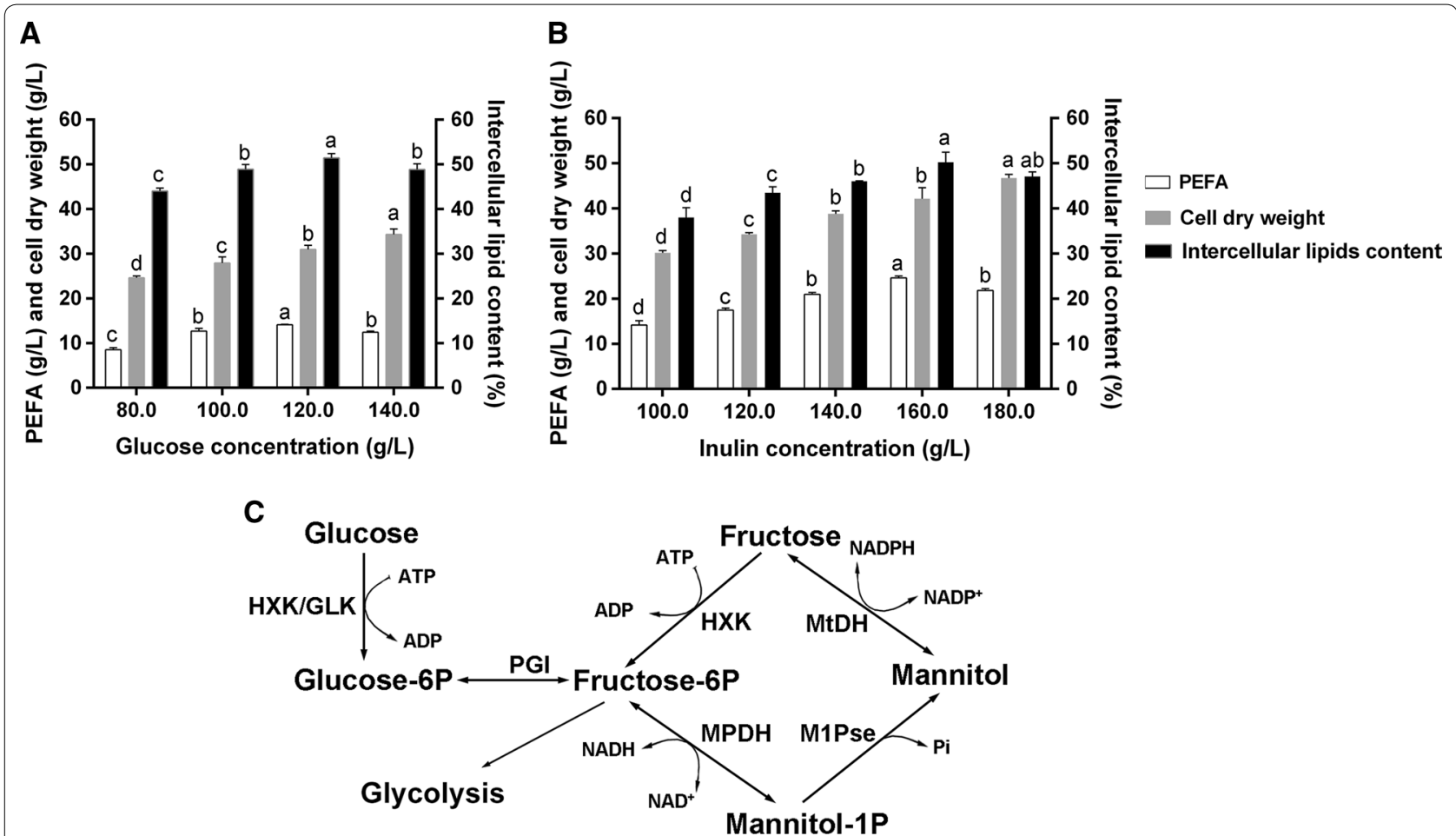

Fig. 4 Effects of different concentrations of different concentrations of glucose (A) and different concentrations of inulin (B) on PEFA production, intercellular lipid content and cell growth. The values were means of three independent determinations. ${ }^{a, b, c, d}$ Mean values with different superscript letters differ significantly and were determined statistically as mentioned in "Materials and methods" (one way ANOVA, Tukey, $P<0.05$ ). Separate analysis was done for the groups of PEFA, cell dry weight and intercellular lipids content. C Mannitol biosynthetic pathway in fungi. HXK, hexokinase; GLK, glucose kinase; MtDH, mannitol dehydrogenase; MPDH, mannitol-1-phosphate dehydrogenase; M1 Pse, mannitol-1-phosphate phosphatase

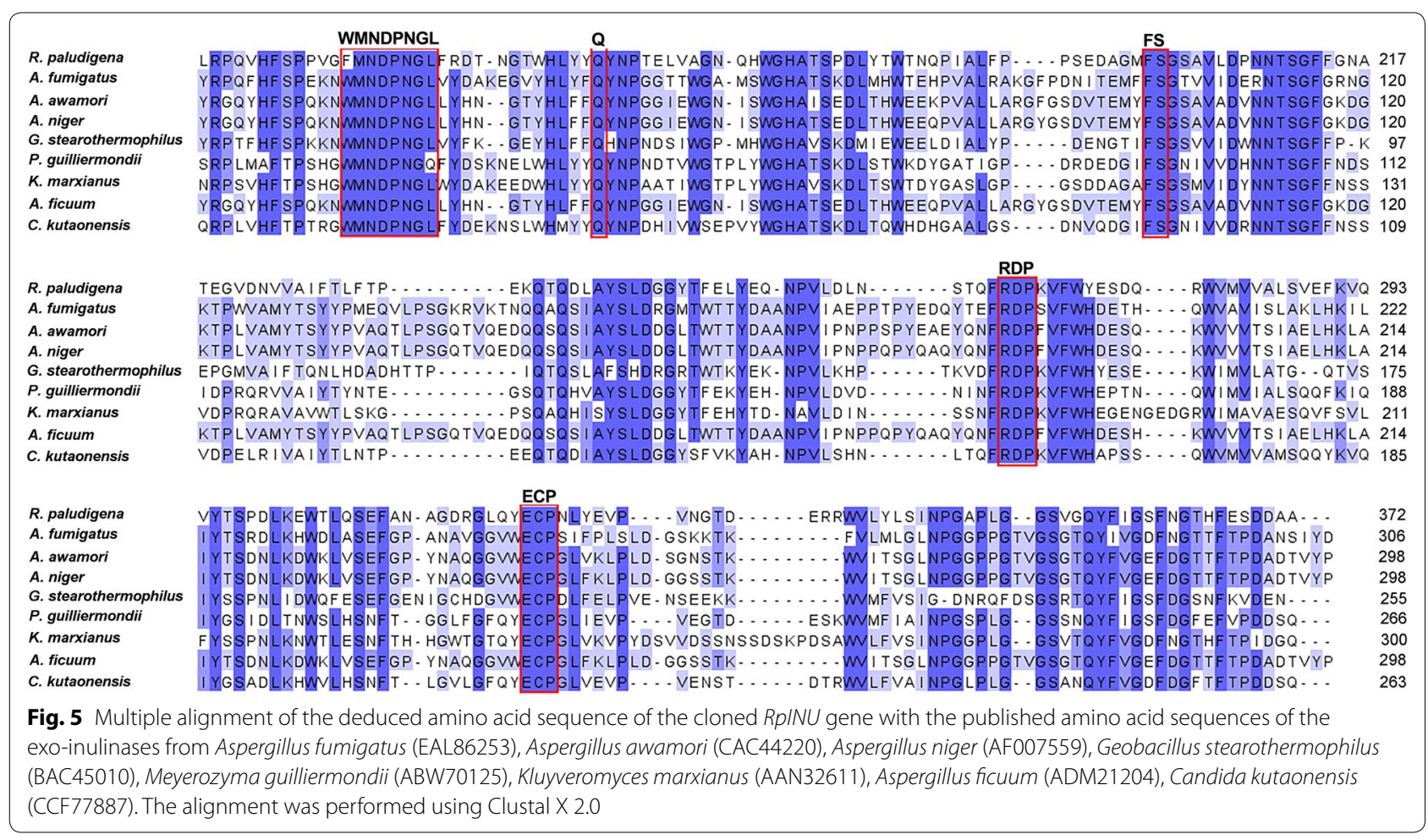


$\mathrm{Glu}^{320}$ of the deduced amino acids acted as a nucleophile and an acid/base catalyst, respectively. These results confirmed that the yeast strain P4R5 indeed had the RpINU gene encoding an exo-inulinase.

Subsequently, effect of different concentrations of inulin on PEFA and intracellular lipids production was investigated. As shown in Fig. 4B, when the medium contained $120.0 \mathrm{~g} / \mathrm{L}$ inulin, the strain P4R5 could produce the PEFA of $17.4 \mathrm{~g} / \mathrm{L}$, which was significantly higher than the analogue $(14.1 \mathrm{~g} / \mathrm{L})$ when the medium contained the optimum glucose concentration of $120.0 \mathrm{~g} / \mathrm{L}$ (t-test, $P<0.01$ ) (Fig. 4A). Furthermore, Fig. $4 \mathrm{~B}$ indicated that the amounts of PEFA and intracellular lipids were raised progressively with increasing of inulin supply, and reached their maximum of $24.6 \mathrm{~g} / \mathrm{L}$ and $21.1 \mathrm{~g} / \mathrm{L}$ (lipids content of $50.2 \%$ $(\mathrm{w} / \mathrm{w})$ ) within $144 \mathrm{~h}$, respectively, at a inulin concentration of $160.0 \mathrm{~g} / \mathrm{L}$. These results indicated that inulin was a kind of more superior carbon resource than glucose for the PEFA yield in the strain P4R5. According to the previous literatures and the structure analyzed above (Table 2 and Fig. 3) [12, 27], the PEFA biosynthetic pathway in $R$. paludigena P4R5 is probable that the formation of the fatty acid portion of PEFA undergoes a similar biosynthetic pathway to that of triacylglycerol, followed by hydroxylation and esterification with a polyol group of mannitol. For fatty acid synthesis, inulin and glucose share the same metabolic pathways, because the inulin hydrolysis products are mainly fructose and a small amount glucose [20]. However, the mannitol synthesis initiated by fructose is different from that initiated by glucose, on the basis of the reported biosynthetic pathway in fungi [28]. Specifically, as shown in Fig. 4C, fructose can be directly converted into mannitol by mannitol dehydrogenase $(\mathrm{MtDH})$ at the cost of a molecule of $\mathrm{NADPH}$, while glucose is converted into mannitol in a four-step process that includes hexokinase (HXK), phosphoglucose isomerase (PGI), mannitol-1-phosphate dehydrogenase (MPDH) and mannitol-1-phosphate phosphatase (M1Pse). This meant that the conversion of glucose into mannitol consumes an extra molecule of ATP compared with that of fructose (Fig. 4C). Thus, it could be concluded that inulin was more efficient than glucose for mannitol synthesis in yeast cells. Therefore, utilizing inulin as carbon resource for PEFA production, the improvement of the PEFA yield was probably ascribed to the enhanced efficiency of mannitol synthesis. This conclusion showed good agreements with a previous study that the PEFA yield of the strain $R$. aff. paludigena UCDFST 81-84 using sucrose was higher than that obtained with glucose [12]. Because similar to inulin, the hydrolysis products of sucrose are also fructose and glucose. Besides, another probable reason was that inulin caused an lower osmotic stress on yeast cells than glucose under the same concentration. In conclusion, inulin, a promising alternative to glucose, exhibited significant advantages as a carbon source in PEFA production.

\section{PEFA and intracellular lipids production from inulin in a 10-L batch bioreactor}

Taking into account high levels production of intracellular lipids and extracellular PEFA, the strain $R$. paludigena P4R5 was selected for larger-scale work using the optimized PEFA production medium containing inulin. As shown in Fig. 6, the inulinase activity reached $65.0 \pm 0.7$ $\mathrm{U} / \mathrm{mL}$ within $60 \mathrm{~h}$, which was much more than any other oleaginous yeast strains reported so far, such as $R$. toruloides 2F5 (7.5 U/mL) [25] and P. guilliermondii Pcla22 $(11.5 \mathrm{U} / \mathrm{mL})$ [24]. This allowed the strain P4R5 to efficiently produce PEFA and intracellular lipids from inulin. For intracellular lipids, during the first $48 \mathrm{~h}$, its amount increased exponentially to reach $51.1 \%(\mathrm{w} / \mathrm{w})$. Thereafter, its accumulation fell gradually to about $40 \%(\mathrm{w} / \mathrm{w})$ after $168 \mathrm{~h}$ of culture. In contrast, the production of PEFA began at $36 \mathrm{~h}$, and its titer was raised dramatically to achieve a maximum of $48.5 \pm 0.2 \mathrm{~g} / \mathrm{L}$ within $156 \mathrm{~h}$, with cell dry weight and oil content of $40.6 \pm 1.2 \mathrm{~g} / \mathrm{L}$ and $41.6 \pm 1.6 \%$, respectively (Fig. 6). These results suggested that, in addition to the newly synthesized fatty acids, the storage lipid also could be mobilized for the PEFA synthesis. In the meantime, the lipid production was accompanied by a massive consumption of inulin, and $5.1 \%$ residual total sugar remained at the end of the fermentation period (Fig. 6). Finally, 0.32 g/g of extracellular PEFA and $0.11 \mathrm{~g} / \mathrm{g}$ of the intracellular lipids were generated at 0.31 and $0.11 \mathrm{~g} / \mathrm{h} / \mathrm{L}$ productivity levels within $156 \mathrm{~h}$, respectively. Previously, several successful attempts made to simultaneously produce extracellular PEFA and intracellular lipids using Rhodotorula strains in the bioreactor level, indicating the PEFA yields ranging from 12.3 to $31.2 \mathrm{~g} / \mathrm{L} \mathrm{[12].} \mathrm{For} \mathrm{example,} \mathrm{in} \mathrm{a} \mathrm{7-L} \mathrm{biore-}$ actor the yeast strain $R$. aff. paludigena UCDFST 81-84 could secret $20.9 \mathrm{~g} / \mathrm{L}$ PEFA and produced $8.8 \mathrm{~g} / \mathrm{L}$ TG, while the yeast strain $R$. babjevae UCDFST 04-877 could produce $11.2 \mathrm{~g} / \mathrm{L}$ PEFA and $18.5 \mathrm{~g} / \mathrm{L}$ TG, with overall glucose conversion rates of 0.24 and $0.22 \mathrm{~g}_{\text {(total lipid) }} / \mathrm{g}_{\text {(glucose) }}$, respectively [15]. This demonstrated that the deep-sea strain R. paludigena P4R5 used in this study was a prominent candidate for the production of PEFA and intracellular lipids on a large scale in industry because of its high PEFA yield, conversion rate and productivity. 


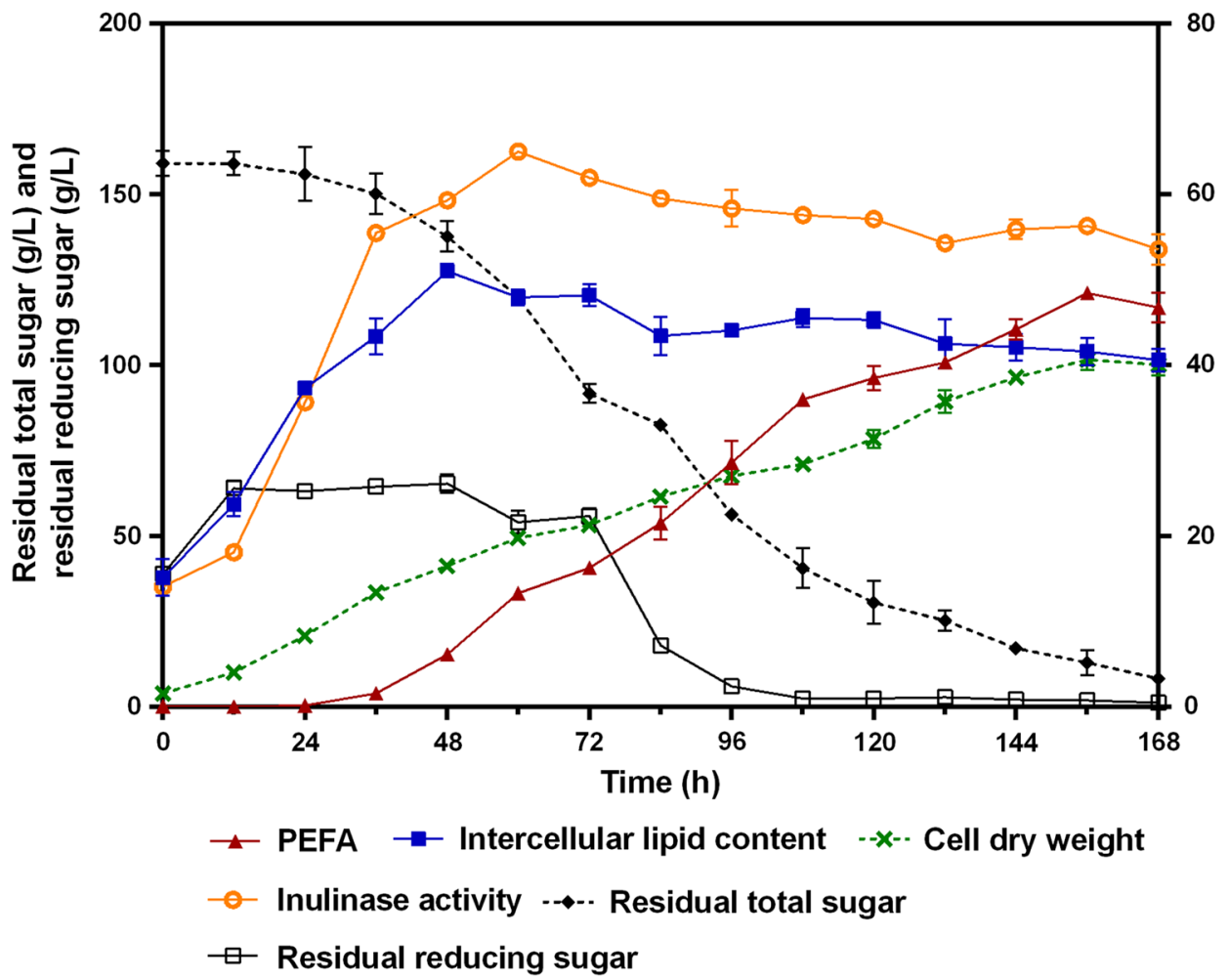

residual total sugar during 10-L fermentation of the strain R4P5. The values were means of three independent determinations

\section{Physicochemical properties of the PEFA produced by $R$. paludigena P4R5}

Biosurfactants reduce the surface (liquid-air) and interfacial (liquid-liquid) tension between two dissimilar phases and allow them to mix and interact more easily. The surface tension decreases gradually with increasing the concentration of biosurfactants until the critical micelle concentration (CMC) is obtained [7]. At concentrations above the $\mathrm{CMC}$, biosurfactant molecules associate to form micelles, bilayers and vesicles, and the surface tension remains almost constant [7]. Figure 7a showed the plotting of surface tension versus logarithmic concentration $(\mathrm{mg} / \mathrm{L})$ of PEFA produced by the strain P4R5. The surface tension of pure water decreased gradually with increasing PEFA concentration to $33.84 \mathrm{mN} / \mathrm{m}$, with a CMC value of $13.18 \mathrm{mg} / \mathrm{L}$. So far, CMC values at a wide range from 5 to $386 \mathrm{mg} / \mathrm{L}$ have been reported for biosurfactants [29]. This suggested that the PEFA produced by the strain P4R5 was efficient, considering that surfactant of low concentration was enough to decrease the surface tension. Generally, the most active biosurfactants can lower the surface tension of water from 72 to approximately $30 \mathrm{mN} / \mathrm{m}$ [7]. With regard to the PEFA produced by Rhodotorula spp., the reported minimum surface tensions ranged from 30.4 to $35 \mathrm{mN} / \mathrm{m}$ [12-14]. For example, PEFA mixtures produced by $R$. aff. paludigena UCDFST 81-84 with a minimum surface tension of $33.3 \mathrm{mN} / \mathrm{m}$ showed antifoam activity comparable to commercial antifoaming agents used in the brewing industry. In another study, the biosurfactant produced by $R$. babjevae YS3 with a minimum surface tension of $32.6 \mathrm{mN} / \mathrm{m}$ exhibited antifungal activity against a considerably broad group of pathogenic fungi [13], while the PEFA from $R$. babjevae Y-SL7 showed a cytotoxic effect against different cancer cell lines [17]. Therefore, the PEFA produced by the strain P4R5 with a surface tension of $33.84 \mathrm{mN} / \mathrm{m}$ at the $\mathrm{CMC}$ value of $13.18 \mathrm{mg} / \mathrm{L}$ has promising application prospects.

In addition, the emulsification activity of the PEFA produced by the strain P4R5 was also investigated on different hydrophobic substrates and compared with commercial biosurfactants Tween 80. As shown in Fig. 7b, the PEFA possessed higher emulsification indexs towards diesel $(77.0 \%)$ and alkanes $\left(E_{24}\right.$ values ranged from 70.7 to $63.4 \%)$ than those towards fatty acid esters. Intriguingly, the emulsification ability of the PEFA was significantly better than that of Tween 80 in the presence of diesel, 

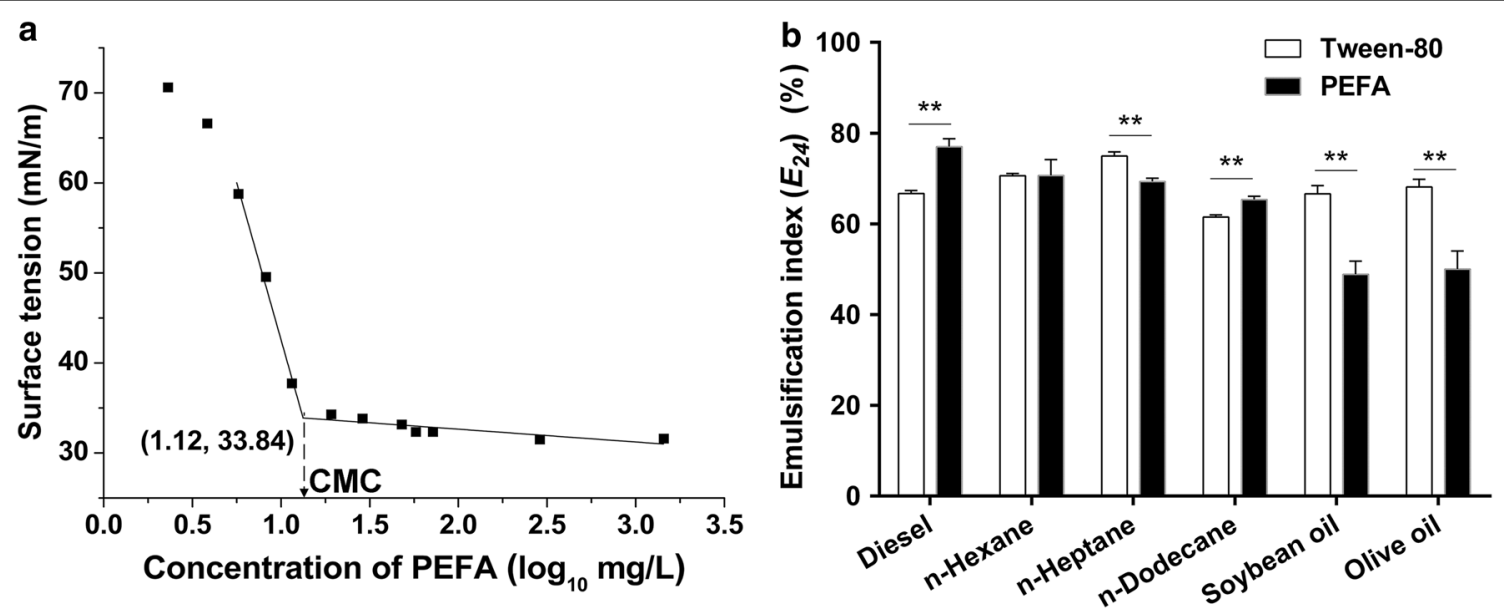

Fig. 7 a Surface tension as a function of biosurfactant concentration. CMC represents critical micelle concentration. b The emulsification activity of the PEFA produced by strain R4P5 on different hydrophobic substrates and comparing with Tween-80. The values were means of three independent determinations. Means between the groups of Tween- 80 and PEFA were compared and analyzed using t-test $\left({ }^{*} P<0.05,{ }^{* *} P<0.01\right)$

indicating that the PEFA from $R$. paludigena P4R5 had an environmental interest in the biodegradation of polluting fossil fuels. Similarly, a recent publication by Guerfali et al. [17] revealed the PEFA from the strain $R$. babjevae Y-SL7 showed higher emulsification indexs towards diesel and mineral oil than those towards vegetable oils. In another study, a biosurfactant produced by Halomonas sp. MB-30 exhibited very high emulsification activity towards crude oil and kerosene, thus it could be used for in situ biosurfactant-mediated enhanced oil recovery process [30].

\section{Properties of the biodiesel prepared using intracellular lipids produced by $R$. paludigena P4R5}

Biodiesel have gained much attention because of its nontoxicity, renewability, biodegradability, inherent lubricity, low or no sulfur content, high flash point, and the reduction of most regulated exhaust emissions [31]. In this study, in addition to PEFA, the strain $R$. paludigena P4R5 could simultaneously accumulate large amount of intracellular lipids (Fig. 6), which were mainly $\mathrm{C}_{16}-\mathrm{C}_{18}$ fatty acids (Table 1) and could be used for biodiesel production. Therefore, the intracellular lipids obtained from the cells of $R$. paludigena P4R5 were converted into biodiesel. As shown in Fig. 8, it was found that the prepared biodiesels could be burnt well. Considering that direct measurement of fuel properties of biodiesel is quite complex with high cost, high error in reproducibility and requiring a considerable amount of fuel sample, prediction models and mathematical equations have been developed to predict biodiesel properties from fatty acid methyl ester composition $[32,33]$. In the present study, all the properties of the prepared biodiesel listed in Table 3, including viscosity, specific gravity, cloud point, cetane

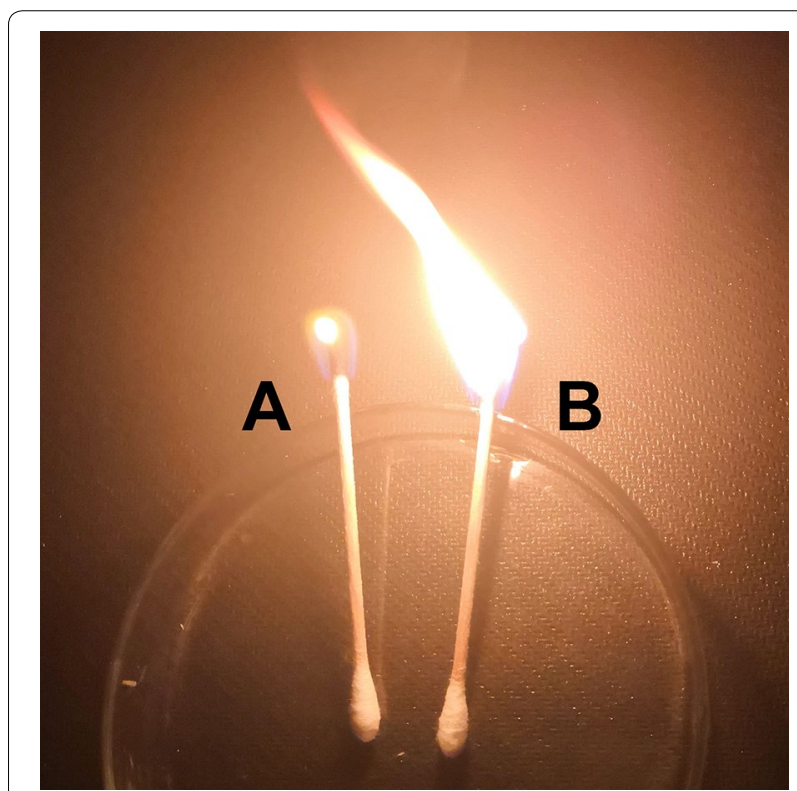

Fig. 8 The burning of the prepared biodiesel from the intracellular lipids of the strain P4R5 (B) and the control without biodiesel (A)

number, iodine number and higher heating value (HHV), were met the US and European specifications for biodiesel. Similar to other biodiesel prepared from microbial lipids, the biodiesel obtained in this study showed lower iodine value and higher cloud point than those of the biodiesel prepared from vegetable oils (soybean and sunflower in Table 3), duo to lower degree of unsaturation. Specifically, the total percentages of $\mathrm{C}_{18: 1}, \mathrm{C}_{18: 2}$ and $\mathrm{C}_{18: 3}$ fatty acids in soybean oil and sunflower oil were $84.09 \%$ and 90.62 [31], respectively, while the analogue in the 
Table 3 Properties of biodiesel from the yeast strain R. paludigena P4R5, soy oil, corn oil, US biodiesel, and EU biodiesel standards

\begin{tabular}{|c|c|c|c|c|c|c|c|}
\hline & Viscosity $\left(\mathrm{mm}^{2} / \mathrm{s}\right)$ & lodine value & Specific gravity & Cetane no. (min) & $\mathrm{HHV}(\mathrm{MJ} / \mathrm{kg})$ & Cloud point $\left({ }^{\circ} \mathrm{C}\right)$ & Ref \\
\hline R. paludigena $\mathrm{P} 4 \mathrm{R} 5^{\mathrm{a}}$ & 4.77 & 63.81 & 0.8764 & 58.29 & 39.74 & 10.82 & This study \\
\hline Soybean & 4.15 & 117.7 & 0.882 & 44.7 & 40.25 & 0.5 & {$[30]$} \\
\hline Sunflower & 4.26 & 128.7 & 0.869 & 45.7 & 35.74 & 0 & {$[30]$} \\
\hline US biodiesel ASTM D6751-08 & $1.9-6.0$ & - & - & 47 & - & - & {$[35]$} \\
\hline Europe biodiesel (EN 14214) & $3.5-5.0$ & $120 \max$ & $0.86-0.9$ & 51 & - & - & [35] \\
\hline
\end{tabular}

a The yeast lipids for biodiesel preparation was produced by R. paludigena P4R5 from inulin within $156 \mathrm{~h}$ during a 10-L batch fermentation

intracellular lipids produced by $R$. paludigena P4R5 was 50.76 (Table 1). Although higher cloud point limits lowtemperature application of biodiesel, but lower iodine values means less sensitive to oxidation and more stable. In addition, the use of edible vegetable oils is associated with serious environmental problem, such as deforestation, destruction of vital soil resources and consumption of much of the arable land. Therefore, lipids from oleaginous yeasts including $R$. paludigena P4R5 may serve as candidates for biodiesel production.

\section{Conclusions}

In this study, a yeast strain R. paludigena P4R5 isolated from deep-sea sediment showed promising biotechnological properties, such as outstanding inulinase activity and the ability of simultaneous high-level production of intracellular microbial lipid and extracellular PEFA. During 10-L batch fermentation, the strain P4R5 could produce $48.5 \mathrm{~g} / \mathrm{L}$ of PEFA and $16.9 \mathrm{~g} / \mathrm{L}$ of intracellular lipid from inulin with the productivity levels of 0.31 and $0.11 \mathrm{~g} / \mathrm{h} / \mathrm{L}$, indicating that the fermentation system for multiple metabolites production was efficient. Structure and physicochemical properties analysis revealed that the PEFA produced by the strain P4R5 was composed of a mixture of mannitol esters of 3-hydroxy $\mathrm{C}_{14}, \mathrm{C}_{16}$ and $\mathrm{C}_{18}$ fatty acids with variable acetylation, and showed promising application prospects as biosurfactant due to its good surface activity and emulsifying activity. In addition, the intracellular lipids, which were mainly $\mathrm{C}_{16}-\mathrm{C}_{18}$ fatty acids, could be used as high-quality feedstock for biodiesel production. These results suggested that the deep-sea yeast strain $R$. paludigena P4R5 was an excellent candidate for industrial production of biosurfactants and biodiesel.

\section{Materials and methods} Yeast strain and media

Yeast strains were isolated from sediment samples from a location of $18^{\circ} 29^{\prime} \mathrm{S}, 129^{\circ} 31^{\prime} \mathrm{W}$ at a depth of $4067 \mathrm{~m}$ in the South Pacific at station BC04 during the 46th Chinese COMRA (China Ocean Mineral Resources Research \&
Development Association) cruise. YPD medium for yeast growth contained $20.0 \mathrm{~g} / \mathrm{L}$ glucose, $10.0 \mathrm{~g} / \mathrm{L}$ yeast extract and $20.0 \mathrm{~g} / \mathrm{L}$ peptone. PEFA screening medium consisted of

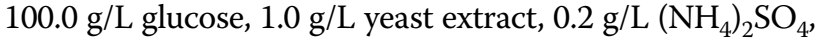
$7.0 \mathrm{~g} / \mathrm{L} \mathrm{KH}_{2} \mathrm{PO}_{4}, 2.5 \mathrm{~g} / \mathrm{L} \mathrm{Na}_{2} \mathrm{HPO}_{4}, 1.5 \mathrm{~g} / \mathrm{L} \mathrm{MgSO}_{4} \cdot 7 \mathrm{H}_{2} \mathrm{O}$, $0.15 \mathrm{~g} / \mathrm{L} \quad \mathrm{CaCl}_{2}, \quad 0.15 \mathrm{~g} / \mathrm{L} \quad \mathrm{FeCl}_{3} \cdot 6 \mathrm{H}_{2} \mathrm{O}, \quad 0.02 \mathrm{~g} / \mathrm{L}$ $\mathrm{ZnSO} 4 \cdot 7 \mathrm{H}_{2} \mathrm{O}$, and $0.02 \mathrm{~g} / \mathrm{L} \mathrm{MnSO}_{4} \cdot \mathrm{H}_{2} \mathrm{O}$. Inulinase production medium was composed of $20.0 \mathrm{~g} / \mathrm{L}$ inulin, $10.0 \mathrm{~g} / \mathrm{L}$ yeast extract and $20.0 \mathrm{~g} / \mathrm{L}$ peptone. The optimized medium for PEFA production consisted of $160.0 \mathrm{~g} / \mathrm{L}$ inulin (Pioneer Biotech Co. Ltd., Xian, China), $1.0 \mathrm{~g} / \mathrm{L}$ yeast extract, $0.2 \mathrm{~g} / \mathrm{L}\left(\mathrm{NH}_{4}\right)_{2} \mathrm{SO}_{4}, 7.0 \mathrm{~g} / \mathrm{L} \mathrm{KH}_{2} \mathrm{PO}_{4}, 2.5 \mathrm{~g} / \mathrm{L} \mathrm{Na}_{2} \mathrm{HPO}_{4}$, $1.5 \mathrm{~g} / \mathrm{L} \mathrm{MgSO}_{4} \cdot 7 \mathrm{H}_{2} \mathrm{O}, 0.15 \mathrm{~g} / \mathrm{L} \mathrm{CaCl}_{2}, 0.15 \mathrm{~g} / \mathrm{L} \mathrm{FeCl}_{3} \cdot 6 \mathrm{H}_{2} \mathrm{O}$, $0.02 \mathrm{~g} / \mathrm{L} \mathrm{ZnSO} 4 \cdot 7 \mathrm{H}_{2} \mathrm{O}$, and $0.02 \mathrm{~g} / \mathrm{L} \mathrm{MnSO}_{4} \cdot \mathrm{H}_{2} \mathrm{O}$.

\section{DNA extraction, PCR amplification, DNA sequencing, and phylogenetic analysis}

The genomic DNAs from the isolated deep-sea yeasts were extracted using a TIANamp Yeast DNA Kit (TIANGEN, Beijing, China). Amplification and sequencing of D1/D2 $26 \mathrm{~S}$ rDNA sequences from this yeast strain was performed according to the methods described by Wang et al. [25] using the primers NL-1:5'-GCATATCAATAAGCGGAG GAAAAG-3' and NL-4:5'-GGTCCGTGTTTCAAGACG G-3'. The sequence of D1/D2 26S rDNA (accession numbers: MH754705.1) obtained above was aligned using BLAST analysis (http://blast.ncbi.nlm.nih.gov/Blast.cgi). The sequence which shared over $98 \%$ similarity with currently available sequence was considered to be the same species. The phylogenetic tree was constructed and visualized using Mega 7 software [34].

\section{Screening of the yeast strains for intracellular lipids and PEFA production}

The nineteen Rhodotorula strains isolated (Additional file 1: Table S1) were cultivated in the YPD seed culture medium at $28{ }^{\circ} \mathrm{C}$ and $180 \mathrm{rpm}$ for $16 \mathrm{~h}$, and then $5 \mathrm{~mL}$ of each seed culture was inoculated into the $250-\mathrm{mL}$ flask containing $30.0 \mathrm{~mL}$ of the PEFA screening medium. The flasks were aerobically incubated at $28{ }^{\circ} \mathrm{C}$ and $180 \mathrm{rpm}$ for $144 \mathrm{~h}$. The PEFA, intracellular lipid and cell dry weight were determined as described below. 
Microscopic visualization of PEFA and intracellular lipid The mixture of yeast culture and Nile red solution $(5 \mu \mathrm{g} /$ $\mathrm{mL}$ in DMSO) was incubated at room temperature for $10 \mathrm{~min}$. Visualization was performed under bright field mode and under fluorescence $(530 \mathrm{~nm}$ excitation and $626 \mathrm{~nm}$ emission) at $100 \times$ magnification using a Olympus U-LH100HG fluorescent microscope. The images of the cells were recorded using the cell Sens Standard software.

\section{Optimization of the medium for PEFA production}

The strain P4R5 was cultivated aerobically in the YPD seed culture medium at $28^{\circ} \mathrm{C}$ and $180 \mathrm{rpm}$ for $16 \mathrm{~h}$. A total of $5.0 \mathrm{~mL}$ of the culture was inoculated into the 250 -mL flask containing $30.0 \mathrm{~mL}$ of the PEFA production medium supplemented with different concentrations of glucose and inulin. The flasks were aerobically incubated at $28^{\circ} \mathrm{C}$ and $180 \mathrm{rpm}$ for $144 \mathrm{~h}$. The PEFA, intracellular lipid and cell dry weight were determined as described below.

\section{Ten-liter batch fermentation}

The fermentation for the PEFA and intracellular lipid production was carried out in a 10 -L fermentor (BIOQ6005-6010B, Huihetang Bio-Engineering Equipment (Shanghai) CO-LTD). The seed culture of the yeast strain P4R5 was prepared as described above and inoculated into $7.0 \mathrm{~L}$ of the optimized PEFA production medium with a $10 \%$ inoculation scale. The fermentation was performed under the conditions of the agitation speed of $300 \mathrm{rpm}$, the aeration rate of $600 \mathrm{l} / \mathrm{h}$, the temperature of $28{ }^{\circ} \mathrm{C}$ and the fermentation period of $168 \mathrm{~h}$. Throughout the whole fermentation period, $50.0 \mathrm{~mL}$ of the culture was collected in the interval of $12 \mathrm{~h}$ and used for the determining of the PEFA titer, the content of intracellular oil, inulinase activity, cell density, cell dry weight, and residual reducing sugar and total sugar.

\section{Inulinase activity assay}

The inulinase activity in the supernatant obtained were determined by the method described previously [21]. One unit of inulinase activity was defined as the amount of enzyme that catalyzes the release of $1.0 \mu \mathrm{mol}$ of reducing sugar per min.

\section{Determination of reducing sugar and total sugar}

Reducing sugar was determined using the Nelson-Somogyi method [35]. Total sugar was measured using the same method as reducing sugar after acid hydrolysis with 6.0 $\mathrm{M} \mathrm{HCl}$.

Extraction and quantitative measurements of extracellular PEFA, cell dry weight and intracellular lipids

The PEFA were extracted from the yeast culture according to the reported procedure [17]. Thirty milliliter of culture broth was centrifuged at $8000 \mathrm{~g}$ for $10 \mathrm{~min}$. The precipitate containing cells and extracellular PEFA were further washed twice with $50 \mathrm{~mL}$ of distilled water to remove all traces of culture elements, and then extracted twice with $40 \mathrm{~mL}$ of ethyl acetate for PEFA solubilization. The cell pellet and solubilized PEFA were separated by centrifugation at $8000 \times g$ for $10 \mathrm{~min}$. The solvent containing PEFA was freeze-dried overnight, and the dry weight of the ethyl acetate extract residue was used to estimate grams of PEFA per liter culture. Additionally, the cell pellet was freeze-dried to measure dry cell weight. Subsequently, the obtain dry cell were used for intracellular lipids extraction according to a previous study [36]. Briefly, a known weight (about $100 \mathrm{mg}$ ) of dry cells were lysed in $300 \mu \mathrm{L} 6 \mathrm{~mol} / \mathrm{L} \mathrm{HCl}$ at $100{ }^{\circ} \mathrm{C}$ for $5 \mathrm{~min}$, followed by adding $900 \mu \mathrm{L}$ of chloroform-methanol solution (2:1, $\mathrm{v} / \mathrm{v}$ ). The chloroform phase of the mix was subsequently transferred to a well-weighed glass vial, and vacuum dried at $50{ }^{\circ} \mathrm{C}$ for $30 \mathrm{~min}$. After evaporation of the solvent, the residues were weighed, and the grams of intracellular lipids per gram dry cell weight were calculated.

\section{GC-MS analysis}

For the analysis of the fatty acid composition of PEFA and intracellular oil, the samples extracted above were transmethylated according to the reported procedure [22]. The fatty acid methyl esters (FAMEs) obtained were determined via gas chromatography/mass spectrometry (GC/MS) using an Agilent 7890A gas chromatograph interfaced with an Agilent 5975C mass-selective detector as previously reported [22].

\section{HPLC analysis of polyols and acetic acid}

One gram of the extracted PEFA was thoroughly hydrolyzed by the addition of $10.0 \mathrm{~mL}$ of $2.0 \mathrm{M} \mathrm{NaOH}$ solution. Subsequently, the mixture was extracted with chloroform to remove the generated fatty acid, and the aqueous phase containing the polyols was taken out for chromatographic analysis. HPLC was performed on an Agilent 1100 series HPLC system (Agilent Technologies, Palo Alto, CA, USA) equipped with an refractive index detector using an Aminex HPX-87C analytical column $(300 \times 7.8 \mathrm{~mm})$ (Bio-Rad, USA). HPLC separation was carried out in a eluant of pure water with a flow rate of $0.3 \mathrm{~mL} / \mathrm{min}$. The acetic acid, sorbitol, xylitol, mannitol and arabitol bought from Sigma were used as the standards.

\section{LC-ESI-MS}

LC-ESI-MS analysis of PEFA was performed on a Waters Acquity UPLC H-Class/SQD II system (Waters Corp., Milford, MA, USA), equipped with an ACQUITY UPLC BEH Shield RP18 $(100 \mathrm{~mm} \times 2.1 \mathrm{~mm}, 1.7 \mu \mathrm{m})$ 
column. The chromatography separation was performed as described by Guerfali et al. [17]. The LC-MS instrument was operated in positive ion electrospray mode with an acquisition range of $\mathrm{m} / z$ 115-1700 with a scan rate of $0.5 \mathrm{spectra} / \mathrm{s}$.

\section{Surface tension measurement and critical micelle concentration (CMC)}

The CMC of the PEFA was determined by using the surface tension measurement method [37]. The analysis was performed on a programmable tensiometer (Model K20 Easy Dyne, KRUSS GmbH, Germany) by the Du Nouy ring method under atmospheric pressure and temperature of $25 \pm 1{ }^{\circ} \mathrm{C}$. Surface tensions of the PEFA at the different concentrations ranging from 1 to $1440 \mathrm{mg} / \mathrm{L}$ were recorded until the data were constant. The platinum ring of the tensiometer was cleaned with acetone and flamedried before each measurement.

\section{Emulsification index determination}

Emulsification index $\left(E_{24}\right)$ towards diesel, as well as other hydrophobic substrates including $n$-hexane, $n$-heptane, $n$-dodecane, soybean oil and olive oil, was determined as described by Guerfali et al. [17]. The studied hydrocarbons was added to $20 \mathrm{mg} / \mathrm{mL}$ PEFA in a ratio of $1: 1$ and vortexed vigorously for $2 \mathrm{~min}$. After $24 \mathrm{~h}$ of incubation, the height of the emulsified layer was measured and compared with the total height of the liquid layer and multiplied by $100\left(E_{24}\right)$. Tween 80 was used as a control.

\section{Biodiesel preparation and its properties analysis}

Intracellular lipids extracted from the cells of the strain P4R5 were transformed to biodiesel according to the procedure described [24]. In brief, $2.5 \mathrm{~L}$ fermentation broth harvested at $156 \mathrm{~h}$ from inulin during $10-\mathrm{L}$ batch fermentation in this study were used for intracellular lipids preparation according to the above method. Then, $50.0 \mathrm{~mL}$ of intracellular lipids obtained were mixed with $500 \mathrm{~mL}$ of $0.1 \mathrm{M} \mathrm{H}_{2} \mathrm{SO}_{4}$-methanol solution. The mixture was kept on a magnetic stirrer at $70{ }^{\circ} \mathrm{C}$ with mild mixing for $40 \mathrm{~min}$. After centrifugation at $3000 \times g$ for $10 \mathrm{~min}$, the organic phase (lower phase) was heated at $85^{\circ} \mathrm{C}$ for $90 \mathrm{~min}$ and the residual organic compounds obtained were used as biodiesel. For properties analysis, average unsaturation (AU) was calculated from the fatty acids compositional profiles based on the equation $(\mathrm{AU}=\Sigma \mathrm{N} \times \mathrm{Ci}$, where $\mathrm{N}$ represents the number of carbon-carbon double bonds of unsaturated fatty acids and $\mathrm{Ci}$ represents the percentage of the component). Based on the value of AU, viscosity, specific gravity, cloud point, cetane, iodine number and higher heating value were calculated using the following equations: viscosity $=-0.6316 \times \mathrm{AU}+5.2065$, iodine $\quad$ value $=74.373 \times \mathrm{AU}+12.71, \quad$ Specific gravity $=0.0055 \times \mathrm{AU}+0.8726, \quad$ cetane $=-6.6684 \times \mathrm{A}$ $\mathrm{U}+62.876, \quad \mathrm{HHV}=1.7601 \times \mathrm{AU}+38.534$, and cloud point $=-13.356 \times \mathrm{AU}+19.994[32]$.

\section{Statistical analysis}

All values were means of three separate experiments. The statistical analysis was performed using the GraphPad Prism 6.01 (GraphPad Software Inc., USA). Means were compared and analyzed using either t-test or one way analysis of variance (ANOVA) with Tukey HSD post hoc multiple comparison test. A probability value of $P<0.05$ was considered significant.

\section{Supplementary information}

Supplementary information accompanies this paper at https://doi. org/10.1186/s12934-019-1200-3.

Additional file 1: Table S1. The morphological and physiological characteristics, accession numbers of D1/D2 26S rDNA sequences, identified species, the biomass, intracellular lipids content and PEFA production in the PEFA screening medium of the 19 strains isolated from deep-sea.

\section{Authors' contributions}

MQW and WAM performed all the experiments, statistical analysis, and drafted the manuscript. XXW and FYL performed the strains isolation and identification. ZC and ZMC participated in the study and analyzed the results. JMW performed the variance analysis. GLL directly supervised the experimental design, execution, data analysis and manuscript writing. All authors read and approved the final manuscript.

\section{Funding}

This research was supported by the National Natural Science Foundation of China (No. 31770073), and the Program of Innovation Sources of Qingdao (No. 17-1-1-58-jch)

\section{Ethics approval and consent to participate} Not applicable.

\section{Consent for publication}

I hereby give the Journal of Microbial Cell Factories the right and permission to publish this article.

\section{Competing interests}

The authors declare that they have no competing interests.

\section{Author details}

${ }^{1}$ College of Marine Life Science, Ocean University of China, Yushan Road, No. 5, Qingdao 266003, Shandong, China. ${ }^{2}$ Laboratory for Marine Biology and Biotechnology, Pilot National Laboratory for Marine Science and Technology, No.1 Wenhai Road, Qingdao 266237, China. ${ }^{3}$ Key Laboratory of Biobased Materials, Qingdao Institute of Bioenergy and Bioprocess Technology, Chinese Academy of Sciences, Qingdao 26601, China.

Received: 11 July 2019 Accepted: 27 August 2019

Published online: 03 September 2019

\section{References}

1. Zaky AS, Tucker GA, Daw ZY, Du CY. Marine yeast isolation and industrial application. FEMS Yeast Res. 2014;14:813-25 
2. Nagahama T, Hamamoto M, Nakase T, Takami H, Horikoshi K. Distribution and identification of red yeasts in deep-sea environments around the northwest Pacific Ocean. Antonie van Leeuwenhoek. 2001;80:101-10.

3. Zhu ZW, Zhang SF, Liu HW, Shen HW, Lin XP, Yang F, Zhou YJJ, Jin GJ, Ye $M L$, Zou HF, Zhao ZBK. A multi-omic map of the lipid-producing yeast Rhodosporidium toruloides. Nat Commun. 2012;3:1112.

4. Garay LA, Sitepu IR, Cajka T, Fiehn O, Cathcart E, Fry RW, Kanti A, Nugroho AJ, Faulina SA, Stephanandra S, et al. Discovery of synthesis and secretion of polyol esters of fatty acids by four basidiomycetous yeast species in the order Sporidiobolales. J Ind Microbiol Biotechnol. 2017:44:923-36.

5. Zhuang X, Kilian O, Monroe E, Ito M, Tran-Gymfi MB, Liu F, Davis RW, Mirsiaghi M, Sundstrom E, Pray T, et al. Monoterpene production by the carotenogenic yeast Rhodosporidium toruloides. Microb Cell Fact. 2019;18:54.

6. Banat IM, Franzetti A, Gandolfi I, Bestetti G, Martinotti MG, Fracchia L, Smyth TJ, Marchant R. Microbial biosurfactants production, applications and future potential. Appl Microbiol Biotechnol. 2010;87:427-44.

7. Pacwa-Plociniczak M, Plaza GA, Piotrowska-Seget Z, Cameotra SS. Environmental applications of biosurfactants: recent advances. Int J Mol Sci. 2011;12:633-54

8. Marchant R, Banat IM. Microbial biosurfactants: challenges and opportunities for future exploitation. Trends Biotechnol. 2012;30:558-65.

9. Araujo HWC, Andrade RFS, Montero-Rodriguez D, Rubio-Ribeaux D, da Silva CAA, Campos-Takaki GM. Sustainable biosurfactant produced by Serratia marcescens UCP 1549 and its suitability for agricultural and marine bioremediation applications. Microb Cell Fact. 2019;18:2.

10. Marchut-Mikolajczyk O, Drozdzynski P, Pietrzyk D, Antczak T. Biosurfactant production and hydrocarbon degradation activity of endophytic bacteria isolated from Chelidonium majus L. Microb Cell Fact. 2018;17:171.

11. Cajka T, Garay LA, Sitepu IR, Boundy-Mills KL, Fiehn O. Multiplatform mass spectrometry-based approach identifies extracellular glycolipids of the yeast Rhodotorula babjevae UCDFST 04-877. J Nat Prod. 2016;79:2580-9.

12. Garay LA, Sitepu IR, Cajka T, Xu J, Teh HE, German JB, Pan ZL, Dungan SR, Block DE, Boundy-Mills KL. Extracellular fungal polyol lipids: a new class of potential high value lipids. Biotechnol Adv. 2018;36:397-414.

13. Sen S, Borah SN, Bora A, Deka S. Production, characterization, and antifungal activity of a biosurfactant produced by Rhodotorula babjevae YS3. Microb Cell Fact. 2017;16:95.

14. Lyman M, Rubinfeld B, Leif R, Mulcahy H, Dugan L, Souza B. Rhodotorula taiwanensis MD1149 produces hypoacetylated PEFA compounds with increased surface activity compared to Rhodotorula babjevae MD1169. PLoS ONE. 2018;13:e0190373.

15. Garay LA, Sitepu IR, Cajka T, Cathcart E, Fiehn O, German JB, Block DE, Boundy-Mills KL. Simultaneous production of intracellular triacylglycerols and extracellular polyol esters of fatty acids by Rhodotorula babjevae and Rhodotorula aff. paludigena. J Ind Microbiol Biotechnol. 2017:44:1397-413.

16. Li YH, Zhao ZB, Bai FW. High-density cultivation of oleaginous yeast Rhodosporidium toruloides Y4 in fed-batch culture. Enzyme Microb Technol. 2007:41:312-7.

17. Guerfali M, Ayadi I, Mohamed N, Ayadi W, Belghith H, Bronze MR, Ribeiro MHL, Gargouri A. Triacylglycerols accumulation and glycolipids secretion by the oleaginous yeast Rhodotorula babjevae Y-SL7: structural identification and biotechnological applications. Bioresour Technol. 2019;273:326-34

18. Tang RR, Chi Z, Jiang H, Liu GL, Xue SJ, Hu Z, Chi ZM. Overexpression of a pyruvate carboxylase gene enhances extracellular liamocin and intracellular lipid biosynthesis by Aureobasidium melanogenum M39. Process Biochem. 2018;69:64-74.

19. Huang C, Chen XF, Xiong L, Chen XD, Ma LL, Chen Y. Single cell oil production from low-cost substrates: the possibility and potential of its industrialization. Biotechnol Adv. 2013;31:129-39.
20. Liu GL, Chi Z, Chi ZM. Molecular characterization and expression of microbial inulinase genes. Crit Rev Microbiol. 2013;39:152-65.

21. Liu GL, Fu GY, Chi Z, Chi ZM. Enhanced expression of the codonoptimized exo-inulinase gene from the yeast Meyerozyma guilliermondii in Saccharomyces sp. W0 and bioethanol production from inulin. Appl Microbiol Biotechnol. 2014;98:9129-38.

22. Shi NC, Mao WA, He XX, Chi Z, Chi ZM, Liu GL. Co-expression of exoinulinase and endo-inulinase genes in the oleaginous yeast Yarrowia lipolytica for efficient single cell oil production from inulin. Appl Biochem Biotechnol. 2018;185:334-46.

23. Kurtzman C, Fell JW, Boekhout T. The yeasts: a taxonomic study. Amsterdam: Elsevier; 2011.

24. Wang GY, Chi Z, Song B, Wang ZP, Chi ZM. High level lipid production by a novel inulinase-producing yeast Pichia guilliermondii Pcla22. Bioresour Technol. 2012;124:77-82.

25. Wang ZP, Fu WJ, Xu HM, Chi ZM. Direct conversion of inulin into cell lipid by an inulinase-producing yeast Rhodosporidium toruloides 2F5. Bioresour Technol. 2014;161:131-6.

26. Ageitos JM, Vallejo JA, Veiga-Crespo P, Villa TG. Oily yeasts as oleaginous cell factories. Appl Microbiol Biotechnol. 2011;90:1219-27.

27. Van Bogaert INA, Holvoet K, Roelants SLKW, Li B, Lin YC, Van de Peer Y, Soetaert W. The biosynthetic gene cluster for sophorolipids: a biotechnological interesting biosurfactant produced by Starmerella bombicola. Mol Microbiol. 2013:88:501-9.

28. Aguilar-Osorio G, vanKuyk PA, Seiboth B, Blom D, Solomon PS, Vinck A, Kindt F, Wosten HAB, de Vries RP. Spatial and developmental differentiation of mannitol dehydrogenase and mannitol-1-phosphate dehydrogenase in Aspergillus niger. Eukaryot Cell. 2010;9:1398-402.

29. Abbasi H, Hamedi MM, Lotfabad TB, Zahiri HS, Sharafi H, Masoomi F, Moosavi-Movahedi AA, Ortiz A, Amanlou M, Noghabi KA. Biosurfactantproducing bacterium, Pseudomonas aeruginosa MA01 isolated from spoiled apples: physicochemical and structural characteristics of isolated biosurfactant. J Biosci Bioeng. 2012;113:211-9.

30. Dhasayan A, Kiran GS, Selvin J. Production and characterisation of glycolipid biosurfactant by Halomonas sp. MB-30 for potential application in enhanced oil recovery. Appl Biochem Biotechnol. 2014;174:2571-84.

31. Sajjadi B, Raman AAA, Arandiyan H. A comprehensive review on properties of edible and non-edible vegetable oil-based biodiesel: composition, specifications and prediction models. Renew Sustain Energy Rev. 2016;63:62-92.

32. Hoekman SK, Broch A, Robbins C, Ceniceros E, Natarajan M. Review of biodiesel composition, properties, and specifications. Renew Sustain Energy Rev. 2012;16:143-69.

33. Khot M, Kamat S, Zinjarde S, Pant A, Chopade B, RaviKumar A. Single cell oil of oleaginous fungi from the tropical mangrove wetlands as a potential feedstock for biodiesel. Microb Cell Fact. 2012;11:71.

34. Kumar S, Stecher G, Tamura K. MEGA7: molecular evolutionary genetics analysis version 7.0 for bigger datasets. Mol Biol Evol. 2016;33:1870-4.

35. Marais JP, De Wit JL, Quicke GV. A critical examination of the Nelson-Somogyi method for the determination of reducing sugars. Anal Biochem. 1966;15:373-81.

36. Zhang H, Wang Z, Feng Y, Cui Q, Song X. Phytohormones as stimulators to improve arachidonic acid biosynthesis in Mortierella alpina. Enzyme Microb Technol. 2019;131:109381.

37. Baruah A, Pathak AK, Ojha K. Study on the thermal stability of viscoelastic surfactant-based fluids bearing lamellar structures. Ind Eng Chem Res. 2015;54:7640-9.

\section{Publisher's Note}

Springer Nature remains neutral with regard to jurisdictional claims in published maps and institutional affiliations. 